\title{
Facilitating Low-Carbon Living? A Comparison of Intervention Measures in Different Community-Based Initiatives
}

\author{
Martina Schäfer ${ }^{1, *}$, Sabine Hielscher ${ }^{1}$, Willi Haas ${ }^{2}{ }^{\mathbb{D}}$, Daniel Hausknost ${ }^{3}{ }^{\mathbb{D}}$, Michaela Leitner $^{4}$, \\ Iris Kunze ${ }^{5}$ and Sylvia Mandl ${ }^{4}$ \\ 1 Center for Technology and Society, Technische Universität Berlin, Sekr. HBS 1, Hardenbergstraße 16-18, \\ D-10623 Berlin, Germany; hielscher@ztg.tu-berlin.de \\ 2 Institute for Social Ecology, University of Natural Resources and Life Sciences (BOKU), Schottenfeldgasse 29, \\ A-1070 Vienna, Austria; willi.haas@boku.ac.at \\ 3 Institute for Social Change and Sustainability (IGN), Vienna University of Economics and Business, \\ Welthandelsplatz 2, A-1020 Vienna, Austria; daniel.hausknost@wu.ac.at \\ 4 Austrian Institute for Sustainable Development, Lindengasse 2/12, A-1070 Wien, Austria; \\ michi_leitner@gmx.at (M.L.); sylvia.mandl@liwest.at (S.M.) \\ 5 Center for Global Change and Sustainability ( $\mathrm{gW} / \mathrm{N})$, University of Natural Resources and Life \\ Sciences (BOKU), Borkowskigasse 4/4, A-1190 Vienna, Austria; iris.kunze@boku.ac.at \\ * Correspondence: schaefer@ztg.tu-berlin.de; Tel.: +49-30-314-26854
}

Received: 25 December 2017; Accepted: 28 March 2018; Published: 2 April 2018

\begin{abstract}
The challenge of facilitating a shift towards sustainable housing, food and mobility has been taken up by diverse community-based initiatives ranging from "top-down" approaches in low-carbon municipalities to "bottom-up" approaches in intentional communities. This paper compares intervention measures in four case study areas belonging to these two types, focusing on their potential of re-configuring daily housing, food, and mobility practices. Taking up critics on dominant intervention framings of diffusing low-carbon technical innovations and changing individual behavior, we draw on social practice theory for the empirical analysis of four case studies. Framing interventions in relation to re-configuring daily practices, the paper reveals differences and weaknesses of current low-carbon measures of community-based initiatives in Germany and Austria. Low-carbon municipalities mainly focus on introducing technologies and offering additional infrastructure and information to promote low-carbon practices. They avoid interfering into residents' daily lives and do not restrict carbon-intensive practices. In contrast, intentional communities base their interventions on the collective creation of shared visions, decisions, and rules and thus provide social and material structures, which foster everyday low-carbon practices and discourage carbon-intensive ones. The paper discusses the relevance of organizational and governance structures for implementing different types of low-carbon measures and points to opportunities for broadening current policy strategies.
\end{abstract}

Keywords: low-carbon municipalities; intentional communities; ecovillages; social practice theories; interventions in practices; low-carbon measures

\section{Introduction}

The combined pressure of global climate change, peak oil, and other environmental challenges are driving agendas towards low-carbon consumption patterns. Despite an increased policy interest in combatting climate change, significant changes in shifting to low-carbon consumption patterns have not yet come about [1]. Spurling et al. [2] point out that the dominant framings of motivating 
changes towards more sustainable ways of living are those of technological innovation and influencing the behavior of individual agents, in particular, by supporting people to make better choices for the environment [3]. The adaption of low-carbon technological innovations and infrastructures are thought to be "capable of sustaining present ways of life but with much lower carbon emission than at present" [4] (p. 32) but leaving daily practices largely unchanged and unquestioned. Individual behavior change programmes are mainly grounded in considering people as rational actors that, for instance, want to save money or addressing attitudes and values in order to develop more sustainable lifestyles, frequently through providing information and/or social marketing campaigns [2]. So far, such approaches have had limited impact $[5,6]$. As a response, they have been criticized for their lack of attention to the fact that individual behavior is embedded in social and material structures that make a change in daily routines very challenging [4].

In parallel to this literature, community-based grassroots organization initiatives with "novel bottom-up solutions for sustainable development and sustainable consumption; solutions that respond to the local situation and the interests and values of the communities involved" [7] (p. 585) have emerged over the last two decades. These initiatives have gained increased interest from policy elites and academics over the last several years, as they are said to play an important role in taking measures that facilitate changes in daily practices and initiating real-world experiments in low-carbon living (see, for instance, [8,9]). They are said to challenge existing values, norms [7], and institutional practices [10]. Further, Seyfang [11] has found that these initiatives have developed novel forms of organization and systems of provision. Academic work on community-based sustainability initiatives has mainly made use of frameworks derived from literature on socio-technical transitions such as strategic niche management and multi-level perspective to conceptualize the activities of these initiatives [12]. This literature has been potentially helpful in focusing attention on the processes through which grassroots innovations play a part in the diffusion of low-carbon technologies. However, little attention has gone into the examination of the dynamics of consumption [13].

In reaction to these critiques, emerging research within environmental sociology has begun to challenge dominant approaches by drawing on the concept of social practices. Taking social practices as the unit of analysis moves the emphasis away from concentrating on diffusing low-carbon technologies and changing the behaviors of individuals to analyzing practices as processes of co-evolving technical, economic, social, and cultural developments [14]. Within this literature, Strengers and Maller [15] have recently stressed the need to examine how existing carbon-intensive practices can be changed and how certain interventions can initiate such changes. In this context, Spurling et al. [2] have introduced three types of "interventions-in-practice": "recrafting practices," "substituting practices," and "changing the ways practices interlock," which, however, have thus far hardly been applied in empirical studies.

Drawing on social practice theory, in this paper, we investigate the low-carbon measures of two types of community-based initiatives: "bottom-up" intentional communities and "top-down" low-carbon municipalities. Their approaches to facilitating low-carbon living, and the challenges they face in trying to implement them over time, can be extremely diverse. While some initiatives tend to focus on sector-specific innovations within housing, food, and mobility, others offer an integrative approach to initiating low-carbon living across the different sectors. Especially intentional communities go beyond efforts to solely reduce $\mathrm{CO}_{2}$ emissions and engage in broader issues than environmental sustainability such as community building and participation (e.g., [16]). Drawing on the intervention framings developed by Spurling et al. [2], we aim to provide a better understanding of the potential to change daily practices associated with differing interventions implemented as a result of community-based initiatives.

Summing up, the paper links literature on community-based initiatives with concepts from social practice theory with the aim to address limitations of the dominant intervention framings of technological innovation and influencing behavior of individual agents. Specifically, this paper addresses the following research questions: How do intentional communities and low-carbon municipalities differently design and implement low-carbon measures? What role do organizational 
structures play when developing low-carbon measures and attempting to reconfigure carbon-intensive practices? The analysis is based on in-depth interviews and workshops with actors from four intentional communities and low-carbon municipalities in Germany and Austria.

The paper is structured as follows: Section 2 briefly provides a background on the two types of community-based initiatives, before Section 3 introduces the literature on social practice theory, focusing particularly on possible ways of intervening in everyday practices. Section 4 introduces the four investigated case studies and outlines the methodological approach in the study. This is then built upon in Section 5 to empirically detail the low-carbon measures implemented in the community-based initiatives, drawing on the three interventions-in-practice concepts. In the discussion, reflections on the differing ways of designing and implementing of low-carbon measures are offered, in particular considering the initiative's organization and governance structures. Finally, we draw conclusions, considering the potential of community-based initiatives to change carbon-intensive practices.

\section{Background: Intentional Communities and Low-Carbon Municipalities}

The term community-based initiative has been used to refer to several differing organizations, groups, settlements, and projects, for example, solar settlements [17], eco-neighborhoods [18], and low-carbon municipalities [19]. Walker and Devine-Wright [20] (p. 497) have argued that the term "community" has been "a much used word that is readily attached to projects," which vary greatly, for instance, in how initiatives organize themselves, how they make decisions, which aims they attempt to achieve, and how they make use of possible outcomes. In this paper, we investigate low-carbon measures and activities of two types of community-based initiatives: intentional communities and low-carbon municipalities. In the following section, we present some of the key characteristics of these two community-based initiatives, including their organizational and governance structures.

The term "intentional community" encapsulates initiatives that are residence-led settlements or neighborhoods with shared property and commons, such as ecovillages and cohousing projects. These initiatives have spread globally over the last two to three decades. There are around "1000 local ecovillage projects and networks worldwide, among them approximately 130 in Europe" ([21] (p. 6), referring to the Global Ecovillage Network (GEN) platform; the GEN has received consultative status with the UN Economic and Social Council (ECOSOC), has been an active participant in the World Social Forum meetings, and is regularly sending representatives to climate summits and/or part of civil society exhibitions). Additionally, there are an estimated "1000 cohousing communities in operation and around the same number in the process of being finished" [22] (p. 578), creating several country-based networks (in this paper, we have particularly focused on ecological-orientated intentional communities). In recent years, governments have started to acknowledge the role of such initiatives within various sustainability agendas, considering them to be "best practice" cases for sustainable living and encouraging them to exchange their experiences with a wider public [23]. In terms of the ecological footprint, some ecovillages have proven to be successful models for reducing energy consumption while maintaining a high level of quality of life [24-29].

Regarding organizational and governance characteristics, intentional communities (ecovillages and cohousing projects) are consciously designed through participatory processes with the aim to live more communally, while frequently creating their own locally owned physical infrastructure and developing novel social and cultural ways of life $[29,30]$. They have collectively bought the land and property, which is in most cases owned by a cooperative. The cooperative follows ecological and social values, for instance, in developing eco-guidelines for the buildings, forestry and agriculture, and affordable housing. The village infrastructure frequently consists of private flats in communally owned housing estates and a variety of shared areas and buildings such as shared kitchens, playgrounds, workshops, gardens, and laundry rooms. In building these settlements, low-carbon technologies are often adopted and climate change adaptation measures are being taken [31]. Although there are many similarities between different types of intentional communities, eco-villages can in some respects also be considered a special subset of co-housing communities as they have a greater focus on sustainable 
living compared with other co-housing communities [32,33]. Intentional communities are not an administrative unit on their own but mostly are part of a municipality.

The organizational and governance structures of low-carbon municipalities are quite different to intentional communities. They are coordinated and implemented by an administrative/political body. Their governance is based on administrative structures that define a community, e.g., municipalities. They draw from resources provided by the administrative structure itself and are typically connected to top-down policy strategies and programmes. The relevance of low-carbon municipalities has already been recognized internationally and globally (see $[8,34])$. The worldwide largest network of low-carbon municipalities and districts that is dedicated to climate protection is the "Climate Alliance," which was founded in Frankfurt in 1990. By now, the network is comprised of more than 1700 municipalities from 26 European countries. With around 950 members, the network is of particular importance to Austria, but there are also around 470 members in Germany. Each member of the Climate Alliance has agreed to contribute to the reduction of greenhouse gas emissions and promotion of environmental justice.

Additionally, in Germany, municipalities can apply to be a recognized low-carbon community through the "National Climate Initiative," which is administrated by the Federal Ministry for the Environment, Nature Conservation, Building and Nuclear Safety. Based on a road map of low-carbon measures, which has to be approved by the municipal council, it is possible to receive funding for a "climate manager" for two to three years. However, prolongation of the funding depends on the successful reduction of greenhouse gases in the first two years, which puts the municipality under pressure to implement effective measures within a rather short period of time. So far, climate protection is no compulsory task for municipalities, as is, e.g., provision with water and energy or educational facilities. This means that especially smaller municipalities normally do not have special financial or personal resources for such a task. A more recent program, the Austrian "e5 program," combines funding possibilities with external audits to implement energy efficiency measures. The aim of the program is to provide low-carbon municipalities with long-term monitoring opportunities connected to climate change. If a municipality has implemented at least half of the agreed measures, it will be awarded the European Energy Award, which has been developed in 2002 in cooperation with partners from Germany, Switzerland, and Poland to form a joint European qualification program for municipalities [35]. By now more than 1300 municipalities all over Europe participate at the program European Energy Award, which is also supported by the European Union [36]. In Germany, the program "Masterplan Kommunen" was initiated in the year 2015 to provide special support to municipalities with very ambitious objectives of reducing energy use and emission of greenhouse gases $(95 \%$ reduction of greenhouse gases and 50\% reduction of end energy consumption until 2050 compared to 1990) [37].

Intentional communities and low-carbon municipalities have attracted the attention of academics for some time now. The work on intentional communities includes studies, for instance, that have examined the potential transformative nature of these initiatives for wider societal changes [29,38-40], have critically interrogated how these initiatives might provide solutions for sustainable living [31,41], and have linked intentional communities to degrowth ideas [22,42]. Other studies have had a narrower focus, looking at the development and potential of renewable energies in these initiatives, innovative uses of time and space [43], or motivations to join them [44]. The work on low-carbon municipalities has mainly concentrated on their responses to climate change mitigation and adaptation targets [19,45-47], examining, for instance, governance issues [48], obstacles for implementing responses [49], and networking activities between initiatives [45].

This paper attempts to address the limitations of dominant intervention framings by comparing low-carbon measures designed by low-carbon municipalities and intentional communities, drawing on social practice theory to frame interventions in practice. By doing so, we seek to provide a better understanding of the potential to change daily practices associated with differing intervention framings. The next section outlines the theoretical framework, drawing on social practices theory. 


\section{Theoretical Framework}

Introducing a practice perspective grounded in social practice theory, Spurling et al. [2] (p. 4) have argued that "social practices are a better target of intervention [ ... ] than 'behavior', 'choice' or technological innovation alone." According to Spurling et al. [2] (p. 4), through a practice perspective the question of changing individual behaviors gets re-framed to "how do we shift everyday practice to be more sustainable" such as heating and cooking. Transformations of daily practices are a result of a co-evolution and/or re-configuring of several interdependent elements within complex socio-technical systems [14]. Drawing on three interventions-in-practice framings outlined by Spurling et al. [2], we compare low-carbon measures within two types of community-based initiatives in order to examine the potential of different intervention framings to change carbon-intensive practices into low-carbon ones.

\subsection{Social Practice Theory}

Social practice theory encourages a shift in analyzing current consumption patterns by focusing on socially shared practices instead of individual behavior. People are viewed as "carriers of practices" [50], who perform regular behavioral routines such as showering, heating, and preparing lunch. Social practices are sustained not merely by norms or rational choices but by their regular performance. Consumption patterns are therefore not necessarily a reflection of individual preferences but rather are perceived to be a result of engaging in practices. The performance of practices relies on co-evolution of the elements that make up a practice. These elements must come together and be aligned to reproduce practices and keep them alive. Practices also exist beyond their performance, as they are socially grounded in shared states of emotions, understandings, and a network of things, norms, and embodied know-how [51,52]. Definitions of the elements of a practice vary [53]; one of the most commonly used versions has been advocated by Shove et al. [54]:

"Meanings refer to ideas, aspirations, values, and symbolic meanings; competences to shared know-how and practical intelligibility; and materials are the physical stuff, such as technologies, objects and infrastructures" ([14] (p. 4), drawing on [54]) (see Figure 1 for an illustration of the linkages between the elements).

Competence: steering, braking, maintenance, repairing

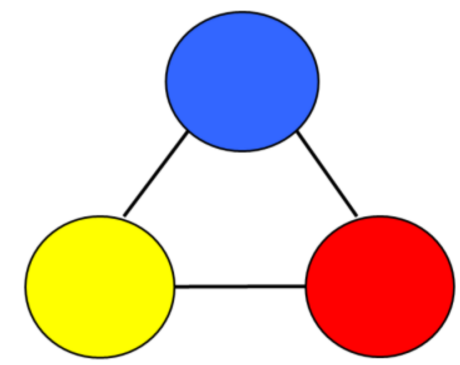

Material: car, streets, traffic signs

Meaning: autonomy, flexibility, convenience

Figure 1. Elements of a practice: driving a car (own design, after [54]).

A more recent development within the literature of social practice theories has been the conceptual development of "bundles of practices" (see, for instance, [54]). Such developments have been based on the recognition that practices do not exist in isolation and are linked together through time and space. They co-evolve to either become incompatible or closely coupled, as such linkages are characterized "as either in harmony or in conflict" ([55] (p. 2), drawing on [56]). For instance, a change to a 
vegetarian diet can re-configure people's cooking and shopping practices and, potentially, connected mobility routines.

\subsection{Interventions-in-Practice}

The regular performance of practices keeps them alive, but is also responsible for their transformation $[51,56,57]$. Transformations can come about through changes in the arrangement of elements-how they fit together [58]. The emergence and disappearance of single social practices can be described by a shift from proto-practices to practices and ex-practices (see Figure 2).

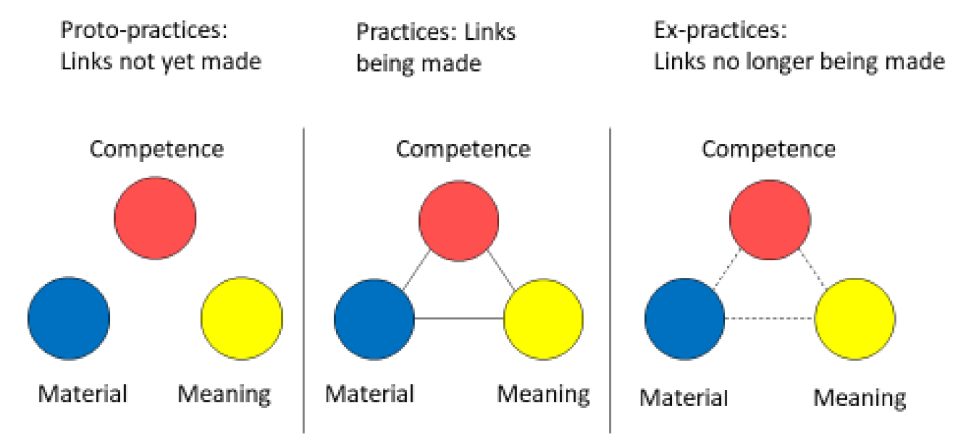

Figure 2. Proto-practices, practices, and ex-practices (own design, after [54] (p. 25)).

Besides the links between different elements, the population of "carriers" of the practice- the people who perform it—can change ([54] and others) through the recruitment to, and deflection and migration from, the practice [59]. Recruitment to practices can occur through social networks (see, for instance, the Nordic walking study [58]), but also by law, material networks, and norms (in the case of daily showering [60]). Moreover, connections between bundles of practice can strengthen or weaken over time. They can become mutually dependent on each other or break apart, which influences the reproduction of practices.

Despite studying such dynamics of practices over time, Strengers and Maller [15] (p. 2) have argued that "social practice theorists have so far had relatively little to say about what it means to intervene in social life; how to go about effecting, steering or governing change; and if this is possible or desirable." One attempt to explore what it means to intervene in daily practice and "open up new 'sites' for policy interventions" [61] (p. 78) has been Spurling et al.'s [2] conceptualization of three intervention framings: (1) "recrafting practices," (2) "substituting practices," and (3) "changing the ways practices interlock" (see Table 1 ).

"Recrafting practices" is grounded in "reducing the resource intensity of existing practices through changing the elements of which they are composed" [61] (p. 79). Interventions can include "the use of new technologies (for example, ultra-low emission vehicles), forms of training (for example, fuel-saver courses) or social marketing and information campaigns" [61] (p. 80). Recrafting can be related to only one of the elements (e.g., installing LED-light) or to several (e.g., installing pellet heating, which also affords acquisition of new competences). Recrafting practices questions neither the necessity of the practice (such as mobility) nor the means to fulfill the practice but aims to reduce its negative effects (see Figure 3).

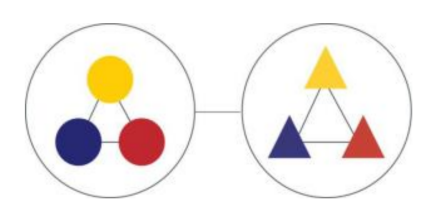

Figure 3. Recrafting practices by changing the elements [2] (p. 10). 
"Substituting practices" focus on "discouraging current unsustainable practices and replacing them with existing or new alternatives" (such as replacing car driving with cycling, see Figure 4). The idea is to change "each of the practices in such a way as to stimulate fewer performances of less sustainable and more performances of sustainable practice" [61] (p. 80). Through this process "the balance of competition between more and less sustainable practice" shifts, i.e., car driving is less frequently performed and cycling is performed more regularly [61] (p. 80). Spurling and McMeekin [61] have argued that the need for a given practice (such as the need for mobility), i.e., its scale, spread, and extent, is not negotiated, but rather the means of performing it (i.e., to cover the same distance by using a bike rather than a car).

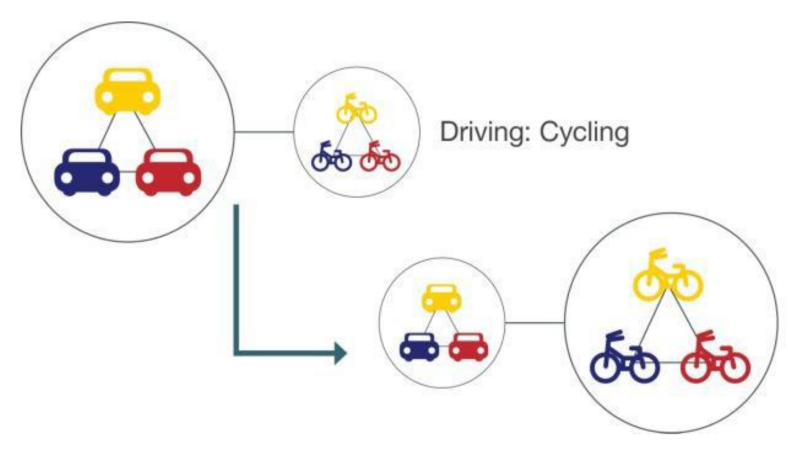

Figure 4. Substituting practices (replacing car driving with cycling) [2] (p. 11).

"Changing the ways practices interlock" focuses on the bundles of practices: "how changing a practice-such as food shopping-has effects on and implications for other practices-such as driving" [2] (p. 51). Here, interventions are based on changing several and sometimes unrelated practices, i.e., beyond the practice itself (driving) and policy area (transport planning) to other practices (see Figure 5). For instance, in relation to the practice of driving, interventions that enable people to walk/cycle to the local shop, grow their own vegetables, or order their food online rather than taking the car to an out-of-town supermarket can become relevant to how often people use their car. The need for a certain practice and its performance is negotiated rather than viewing it as a given.

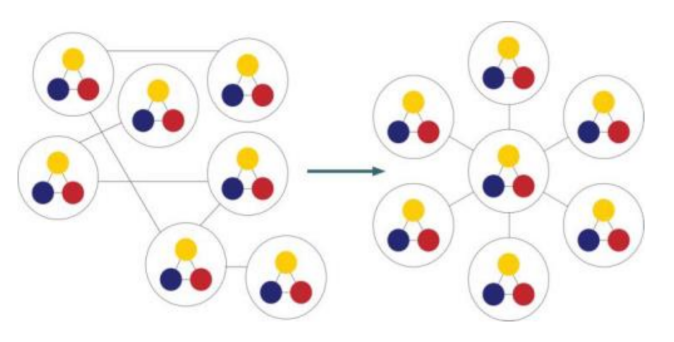

Figure 5. Changing the way practices interlock [2] (p. 13).

These intervention framings have explicitly been developed because social practices are considered to be "a better target of intervention for sustainability policy than 'behavior', 'choice,' or technical innovation alone [2] (p. 4). However, to the best of our knowledge, there are only a handful of studies that have made use of the intervention framings to examine empirically existing low-carbon activities and measures. Examining the practices of housing professionals, Macrorie et al. [62] (p. 108), for instance, have argued for the importance of such "practice-orientated frameworks for policy interventions" and have stressed that it is key not to intervene in single practices but to "prioritise understanding of the flows and relations within and between the practices in question" [62] (p. 109). In this paper, we build on this work by drawing on the three intervention framings to examine the interrelations between low-carbon measures and daily practices within the two types of 
community-based initiatives, comparing their design and implementation of low-carbon measures. The findings presented here are drawn from qualitative research into community-based initiatives. The methodological approach is outlined in the following section.

\section{Methods}

In this empirical paper, we draw from mixed-methods qualitative research into intentional communities (i.e., ecovillages and cohousing communities) and low-carbon municipalities in Austria and Germany. We conducted four in-depth case studies (see Table 1), sampled principally across the two countries for diversity of activities, governance structures, infrastructural arrangements, and pioneer/follow up initiatives. The case studies comprised site visits and in-depth face-to-face interviews with 2-3 informants (such as founders and people involved in the area of mobility, food, and shelter/energy), and were supplemented by a review of self-published material such as websites, promotional materials, and academic reports.

Table 1. Four community-based initiatives.

\begin{tabular}{|c|c|c|c|}
\hline Initiative & Description & Country & Start Date \\
\hline $\begin{array}{l}\text { Cohousing: Lebensraum } \\
\text { Gänserndorf }\end{array}$ & $\begin{array}{l}\text { Lebensraum (living space) is a co-housing project that consists of } 32 \\
\text { clustered, ecologically constructed homes in which currently } 83 \text { people } \\
\text { live. Common facilities consist of a kitchen, dining room, laundry, } \\
\text { playground, and outdoor meeting areas. Lebensraum is a residence-led } \\
\text { non-profit cooperative that owns the real estate and land. }\end{array}$ & Austria & 2001 \\
\hline $\begin{array}{l}\text { Ecovillage: Ökodorf Sieben } \\
\text { Linden }\end{array}$ & $\begin{array}{l}\text { Sieben Linden is an eco-village where } 100 \text { adults and } 40 \text { children have } \\
\text { settled over the years, focusing on closed energy and resource cycles } \\
\text { and building with natural and regional resources like straw, clay, and } \\
\text { timber. Common facilities consist of a kitchen, dining room, } \\
\text { educational center, horticultural areas, etc. Sieben Linden is a } \\
\text { residence-led non-profit cooperative that owns the real estate and land. }\end{array}$ & Germany & 1997 \\
\hline $\begin{array}{l}\text { Low-carbon municipality: } \\
\text { Klimagemeinde Laxenburg }\end{array}$ & $\begin{array}{l}\text { The climate coalition Laxenburg was created in } 2003 \text { and includes one } \\
\text { municipality. Projects have addressed the following areas: sustainable } \\
\text { education, mobility, energy efficiency, renewable energy, etc. }\end{array}$ & Austria & 2003 \\
\hline $\begin{array}{l}\text { Low-carbon municipality: } \\
\text { Klimaregion Beeskow }\end{array}$ & $\begin{array}{l}\text { The climate region Beeskow consists of several municipalities and was } \\
\text { created in 2012. Projects have addressed the following areas: renewable } \\
\text { energy, mobility, sustainable education, etc. }\end{array}$ & Germany & 2012 \\
\hline
\end{tabular}

Additionally, four half-day workshops (one in each initiative) were conducted within the intentional communities and low-carbon municipalities. Between 4 and 6 participants from each initiative attended the workshops (such as founders and a diverse set of people involved in the area of mobility, food, and living). The aim was to discuss initial findings derived from the interviews and document analysis with a larger group of participants. We investigated the historical development of these initiatives and their activities, including important events, experiences, and related social practices in the area of mobility, food, and shelter/energy. In addition to these first-hand accounts, we have drawn upon secondary data through a review of existing academic literature on intentional communities, in particular on ecovillage and cohousing communities (see, for instance, [28,29,43]).

The evidence gathered was originally coded, organized, and interpreted for inductive themes such as governance structures and changing social practices over time and, additionally, we investigated climate change interventions and related social practices in the area of mobility, food, and housing. The aim was to develop an understanding of the everyday practices that are addressed through these interventions and, in particular, the assumed reconfiguration of practice elements. We analyzed the cases according to theoretically informed themes around "recrafting practices," "substituting practices," and "changing the ways practices interlock" and inductive themes, such as the collectivization of daily activities. This in-depth analysis of the intentional communities and low-carbon municipalities has allowed us to gain insight into ways of intervening in social practices, the temporal and spatial arrangements of daily life, and the connections between social practices. These case studies 
were published as "innovation histories" that outline the development of the initiatives and their activities [63-66].

In the next section, we draw on Spurling and McMeekin's [61] work to empirically examine several low-carbon measures within intentional communities and low-carbon municipalities. These measures address the consumption categories of housing, food, and mobility. We have a closer look at the dynamics that are linked to certain low-carbon measures in relation to the intervention framings of "recrafting practices," "substituting practices," and "changing the ways practices interlock."

\section{Analysis of Low-Carbon Measures in Community-Based Initiatives}

The empirical analysis looked at the kinds of low-carbon measures intentional communities and low-carbon municipalities design and implement. They were analyzed in relation to Spurling et al.'s [2] three intervention framings (see Section 3.2), shedding light on the entanglements between social practices and low-carbon measures. The analysis is organized in three sections: "recrafting practices," "substituting practices," and "changing the ways practices interlock".

\section{1. "Recrafting Practices" in Intentional Communities and Low-Carbon Municipalities}

Both of the analyzed intentional communities are involved in "recrafting practices" (see Table 2) across all three consumption categories (food, mobility, and housing). Such "recrafting" processes are regularly grounded in participatory decision-making processes (such as regular plenums), where low-carbon measures are collectively decided, developed, and implemented. Often, such "recrafting" practices are grounded in setting up common rules. For instance, one of the cases collectively decided on on a maximum square metre built-up area allowance per person in order to require less building space and energy to heat living spaces (heating practices). Both of the intentional communities have agreed on zero-energy building standards for their flats and houses. In addition, shared living spaces and multifunctional rooms can be used by all members.

Table 2. Examples of "recrafting practices" across the consumption categories.

\begin{tabular}{|c|c|c|c|c|}
\hline $\begin{array}{c}\text { Consumption } \\
\text { Category }\end{array}$ & Low-Carbon Activities-Practice & Elements of Practice & & \\
\hline & & Material & Meaning & Competences \\
\hline \multicolumn{5}{|c|}{ Intentional community } \\
\hline Housing & $\begin{array}{l}\text { Regulation of } \\
\text { room size-heating }\end{array}$ & $\begin{array}{l}-\quad \text { Smaller rooms } \\
\text { - } \quad \text { Large } \\
\text { common facilities }\end{array}$ & $\begin{array}{ll}\text { - } & \text { All are } \\
\text { equal, eco-simplicity } \\
\text { - } \quad \text { Living a } \\
\text { communal life }\end{array}$ & $\begin{array}{l}\text { - Learning to live in } \\
\text { smaller spaces } \\
\text { - Learning to use common } \\
\text { facilities (such as adapting to } \\
\text { new rules) }\end{array}$ \\
\hline \multicolumn{5}{|c|}{$\begin{array}{l}\text { - "second-rate" fruits } \\
\text { and vegetables }\end{array}$} \\
\hline Mobility & $\begin{array}{l}\text { Cycling with } \\
\text { cargo bikes-cycling }\end{array}$ & - Cargo bikes & - Fossil-free mobility & \\
\hline \multicolumn{5}{|c|}{ Low-carbon municipality } \\
\hline Housing & $\begin{array}{l}\text { Installation of renewable } \\
\text { energy technologies-heating }\end{array}$ & $\begin{array}{l}\text { - Renewable } \\
\text { technologies such as } \\
\text { PV, wood pellet oven }\end{array}$ & $\begin{array}{ll}\text { - } & \text { Low-carbon } \\
\text { energy supply }\end{array}$ & $\begin{array}{l}\text { - Maintaining renewable } \\
\text { energy facilities }\end{array}$ \\
\hline Food & $\begin{array}{l}\text { Information events about } \\
\text { regional food—cooking }\end{array}$ & & $\begin{array}{l}\text { Value of regional } \\
\text { and seasonal } \\
\text { produce (low } \\
\text { food miles) }\end{array}$ & $\begin{array}{l}\text { Learning to cook with } \\
\text { regional/seasonal products }\end{array}$ \\
\hline
\end{tabular}

The creation of common rules frequently goes hand-in-hand with changes to the material infrastructure (e.g., size of the room) and the development of competences (e.g., living in smaller spaces). Efforts to agree on common rules that "enforce" the performance of low-carbon practices can 
sometimes take years within plenums (differing opinions and ideas around low-carbon lifestyles, etc., can be the reason for more lengthy discussions). One of the cases therefore actively encourages diverse performances of practices (such as eating at home or in the communal house). It is recognized that the practices associated with low-carbon living are contested and that experiments are needed to make them livable and to examine their social and environmental impacts when performed in daily life. The analyzed intentional communities often experiment with innovative, sustainable technologies (e.g., pellet heating, loam constructing, composting toilets, and constructed wetlands) and act as pioneers in establishing these technologies. In one of the case studies, it took years for the pellet heating to produce enough heat for the community. The members had to acquire specialized competences of how to operate and maintain the equipment. These processes are accompanied by intense discussions and collective decisions on how to deal with these challenges.

The two low-carbon municipalities are also involved in "recrafting practices" (see Table 2). Such processes occur mainly in the category of housing (and are rather rare within food and mobility). The developments of low-carbon measures often involve local working groups of volunteers (Case Study 2) or the municipalities themselves (Case Study 3). Externally developed climate change strategies often guide the measures. In Germany, these external strategies are helpful in gaining government funding, usually for a two-year period, to implement the low-carbon measures. "Recrafting" efforts are regularly grounded in "offering" or "informing" people about low-carbon alternatives rather than "enforcing" them. They can consist of changing the local infrastructure, such as by installing renewables in municipality-owned buildings (e.g., for heating) or creating events such as monthly energy advice sessions (e.g., for heating, airing, showering, etc.), often only addressing one element of a given daily practice (see Table 2).

Municipalities regularly take a "low-carbon role model" position, hoping that, as a result, the local residents will also engage in low-carbon measures. Low-carbon measures are frequently conducted in parallel to each other rather than linking them up to a coherent strategy, and the local residents are only sometimes engaged or encouraged to participate. For instance, in one of the municipalities, local residents show very little interest in taking up offers to gain free energy advice, which leaves those responsible for implementing low-carbon measures with a feeling and attitude expressed as "we have tried everything" and "what else could we possibly do?"

A comparison of low-carbon measures between the community-based initiative when looking at "recrafting practices" shows that intentional communities more often experiment with "new" and/or "forgotten" elements of practices (e.g., building straw houses). Part of these experimentations are activities that aid the process of creating new competences and changing current daily routines (e.g., chop wood for pellet heating). Low-carbon municipalities mostly draw on more established low-carbon technologies and contract external companies to install and maintain them. While efforts to recraft practices in intentional communities are discussed in the whole community and often have an impact on people's daily practices, the local residents within municipal buildings do not necessarily perceive the changes or need to adapt their daily practices. Participative rule setting, discussions about zero-energy housing standards, and shared values around agricultural and cooking practices often lead to re-configurations of daily practices in intentional communities. In comparison, energy advice in the low-carbon municipalities are voluntary and reach only a small group of residents (and the influences on daily practices are uncertain). Changes to daily routines could mainly be observed within the municipalities' administrative practices (e.g., contracting low-carbon energy providers and monitoring of energy use).

\section{2. "Substituting Practices" in Intentional Communities and Low-Carbon Municipalities}

Both of the intentional communities actively attempt to substitute carbon-intensive practices by "growing" low-carbon alternatives across the consumption categories of food, housing, and mobility. Forms of "substituting practices" are grounded in replacing carbon-intensive practices by (1) reducing their performance, (2) "growing" existing low-carbon practices (that could be performed more often), 
and (3) experimenting with (and growing) relatively novel or "forgotten" low-carbon practices (e.g., preserving vegetables and fruits). As part of these processes, all three elements of a practice are addressed with the intervention. For instance, collective cooking is grounded in changing material elements (such as collectively owned cooking utensils and spaces), meanings (such as collective cooking and eating as an important part of communal living), and competences (such as cooking for a large group of people and dealing with food waste). Practices are frequently changed in such a way (e.g., from individual to communal eating) that new "recruits," i.e., people who perform it [66], need to be acquired if such practices are to survive over time.

"Recruitment processes"-assuring that people regularly perform the practice-are not always straightforward and can take time. For one of the cases (Case Study 2), it took several years until collective eating and cooking was part of the regular routines in the intentional community. Initial issues arose because of the difficulty of synchronizing everyone's routines (i.e., the spatial and temporal organization of daily life, for instance, everybody arriving back from work at 6:00 p.m. to have dinner together) and in developing competences and meanings that worked for all of the members. Efforts to cook restaurant-type food (i.e., cooking several courses with the ambition to cook something "special") did not work; only after relying on home cooking (i.e., standard meals) could people be recruited to the practice on a regular basis. Moreover, building the competence to cook vegetarian meals for a large group of people was aided through cooking in pairs. Such low-carbon measures can entail the development of new organizational and material requirements, i.e., how practices are organized, how they link together, and on which material structures they rely [67]. In addition to replacing practices, both of the intentional communities actively attempt to find ways to discourage carbon-intensive practices. For instance, in one of the cases, car driving and ownership is actively prevented by offering only a few parking spaces, making it socially unacceptable, and by building gravel roads (rather than tarmac roads) in the village. One of the residents pointed to the positive effects of designing the village in this way: "it is in fact a car-free village where children have all the freedom that they need and all of us can move without being afraid that a car will pass." Collective ownership of land and property is an essential basis for implementing these kind of measures [28].

The two low-carbon municipalities also engage in "substituting practices" (see Table 3). Most of these low-carbon measures belong to the category mobility. Measures that relate to food and housing are rather rare (such as "growing" the shopping of organic food). Both of the low-carbon municipalities attempt to increase the performance of cycling and taking public transport within their local area in the hope that people will drive their car less often. This occurs through the installation of bike lanes and bike racks (material element), the set-up of bike rental schemes (material element), the provision of bike checks (competences element), and/or the organization of cycling training (competences element). Both municipalities explored possibilities of installing car sharing options, but either these activities were not sufficiently taken up by the local population or the professional providers were not willing to trial the scheme due to poor economic estimates. Restrictive low-carbon measures that could potentially decrease car driving are not considered (such as providing less parking spaces). The dominance of car driving to commute to work or to shop outside the village is considered to be part of the "normal" way of life in rural areas. The material infrastructures of the local area characterized by the urban sprawl and lack of public transport are regarded as additional difficulties to the development of low-carbon mobility patterns. One of the regional climate managers argued that "the region is so rural and the quality of public transport so bad, that it is plausible that everybody needs a car. It is very difficult to change something in this area." Many solutions are considered to require long-term re-configuration of multi-scale regional planning processes. 
Table 3. Examples of "substituting practices" across the consumption categories.

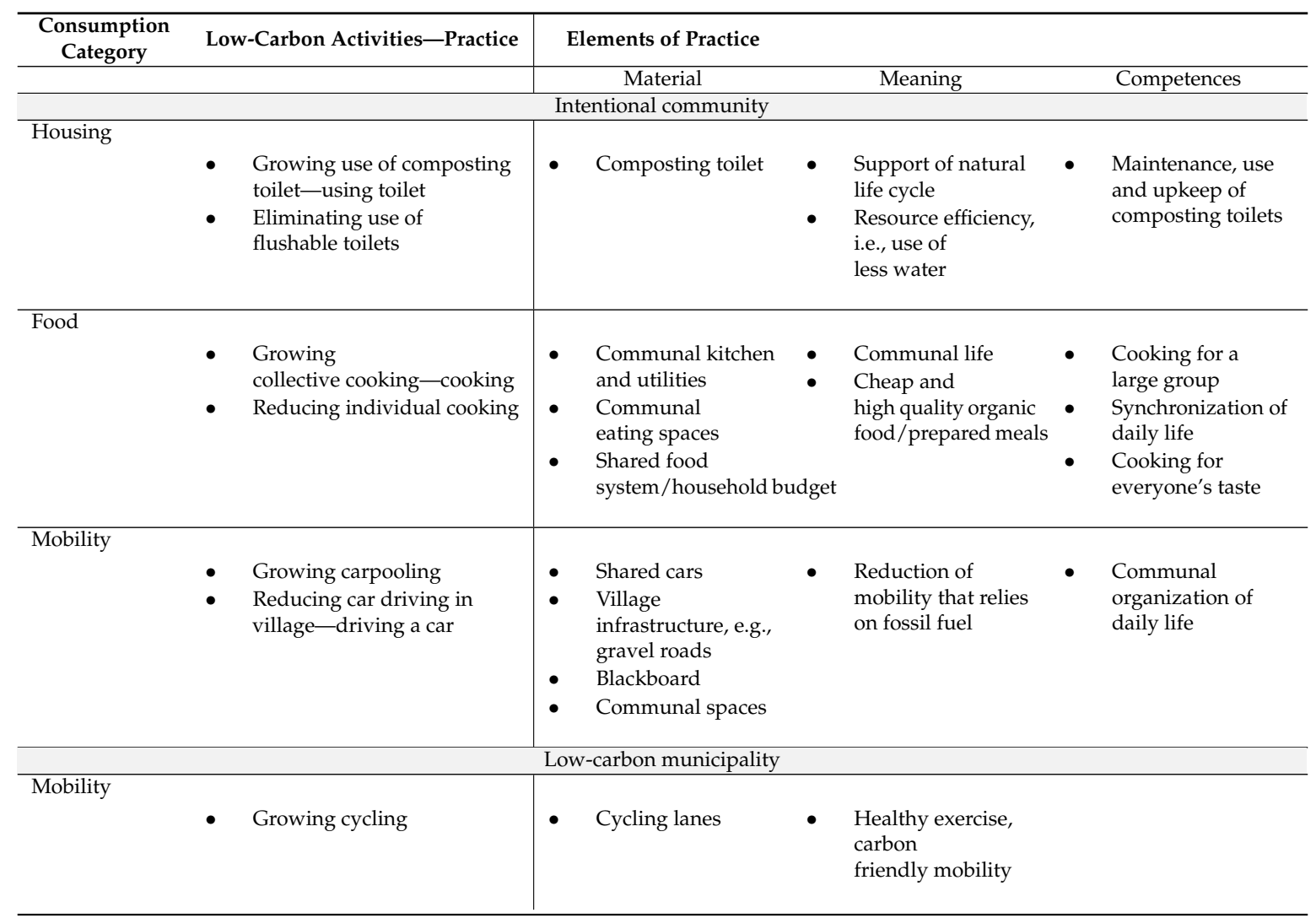

The analysis made apparent that both initiatives attempt to "substitute practices." Low-carbon municipalities regularly attempt to increase low-carbon practices such as cycling or using public transport. Such measures are often conducted in isolation from each other and are rarely grounded in considering how cycling is currently connected to car driving (such as asking the questions of when and why people use the car rather than the bike) and how the uptake of cycling might influence, for instance, how often people use their car (i.e., thinking about the scale and extent of cycling). So far, the low-carbon communities do not really attempt to question today's car dependency; no active attempts are made to "shrink" car driving. It is hoped that people will start using their car less once they cycle more often, but this just as well might not be the case.

In contrast, based on collective decision-making intentional communities are able to take also restrictive measures. They also actively experiment with low-carbon food and housing practices in order to "substitute" carbon-intensive ones. The development of such practices requires experimentation and work. Practices such as preserving food, eating, and cooking communally are not considered "normal," nor are they widely performed - they are so-called "proto-practices" [54]. For instance, intentional communities question their car dependency and experiment with alternative practices even if they are often located in very remote areas. In order to establish private carpooling practices, they have had to experiment with different forms (formal/informal) of performing the practice until carpooling was compatible with existing daily routines. More generally, infrastructures need to be created (such as communal kitchens and food storage), competences need to be acquired (such as how to cook for a large group), working hours need to be synchronized (to be able to eat collectively), and shared meanings need to be found, just to mention a few elements that aid the survival of these practices. These processes can take a long time because changing one practice (such as shifting from family cooking to communal cooking) influences others (such as storing food, buying food, and driving home from work) that are not always easy to foresee. Adjustments and experimentation are needed in order to find configurations of practices that work [67]. 


\section{3. "Changing the Ways Practices Interlock" in Intentional Communities and Low-Carbon Municipalities}

Both of the analyzed intentional communities are also involved in "changing the ways practices interlock" (see Table 4). Institutions (such as creating nurseries and home offices) and communal infrastructures (such as leisure facilities) that are located in the village are created to aid communal living through participatory decision-making processes and frequently shared values. The "co-location" [54] of institutions and material infrastructures render the need for some mobility practices nearly obsolete, including taking children to the nursery and driving to destinations at which leisure activities can take place. As one of the residents puts it, "Of course, it really makes a difference that we can spend our leisure time here. We can dance together, there is cinema, and a sauna. [...] A lot of things happen in the village and then I don't have to go somewhere else." Intentional communities often think about, debate, and attempt to change the "system of practices" [68] (p. 488). For instance, rather than doing individual food shopping trips, food is collectively ordered from organic wholesalers and/or from regional community-supported agriculture farms and/or grown in allotments and horticultural fields, and then collectively preserved, stored, cooked, and eaten, thereby saving packaging and transportation. The performance of one practice heavily relies on the performance of another, creating a network of low-carbon practices. For instance, the practice of collective eating depends heavily on collective food ordering and collective cooking.

Table 4. Examples of "changing the ways practices interlock" across the consumption categories.

\begin{tabular}{|c|c|c|c|c|}
\hline $\begin{array}{c}\text { Type of } \\
\text { Initiative }\end{array}$ & Low-Carbon Activities & Elements of Practice & & \\
\hline & & Material & Meaning & Competences \\
\hline $\begin{array}{l}\text { Intentional } \\
\text { community } \\
\text { Housing }\end{array}$ & $\begin{array}{l}\text { Building play-grounds, } \\
\text { offering yoga classes } \\
\text { and other leisure } \\
\text { activities, creating } \\
\text { nurseries, home offices, } \\
\text { and work-shops }\end{array}$ & $\begin{array}{l}\text { - Communal areas } \\
\text { for communal } \\
\text { services in situ }\end{array}$ & $\begin{array}{ll}\text { - } & \text { Communal living } \\
\text { - } & \text { Improving the } \\
\text { - } & \text { life-work balance } \\
\text { Creating alternative } \\
\text { - } \quad \text { Self-sufficiency }\end{array}$ & $\begin{array}{l}\text { - Organization of } \\
\text { communal daily life } \\
\text { Knowledge of } \\
\text { educational system and } \\
\text { how to set } \\
\text { up alternatives }\end{array}$ \\
\hline $\begin{array}{l}\text { Low-carbon } \\
\text { municipality } \\
\text { Housing }\end{array}$ & $\begin{array}{l}\text { Refurbishing and } \\
\text { taking ownership of } \\
\text { empty buildings and } \\
\text { using them for local } \\
\text { health and } \\
\text { cultural facilities }\end{array}$ & $\begin{array}{ll}\text { - } & \text { Energy } \\
\text { efficiency measures } \\
\text { - } & \text { Local infrastructure }\end{array}$ & $\begin{array}{l}\text { - An attractive village in } \\
\text { which people want to } \\
\text { stay and live } \\
\text { - Solutions that address } \\
\text { shrinking of } \\
\text { rural communities }\end{array}$ & $\begin{array}{l}\text { Knowledge: What } \\
\text { makes an } \\
\text { attractive village } \\
\text { Know-how: how to } \\
\text { gain finances to } \\
\text { refurbish local } \\
\text { buildings and sustain } \\
\text { their upkeep }\end{array}$ \\
\hline
\end{tabular}

Interventions that are connected to changing the ways in which practices interlock within low-carbon municipalities are rather rare (see Table 4). Most of the time, if they do exist, they are not connected to the portfolio of low-carbon measures but rather to other agendas (such as preventing the decline in population in rural areas). "Yeah ..., but this is not at all connected to energy and climate policy ..." ", as argued by one of the local mayors. Endeavors to make the village more attractive for its local residents have become increasingly significant for both of the low-carbon municipalities. Part of these measures is to maintain and create an attractive village center with local shops, a post office, doctors' offices, and leisure activities. One of the cases (Case Study 3) has been particularly active by buying up empty, run-down buildings, installing energy efficiency measures and then opening them up as cinemas, doctors' offices, etc. The upkeep of local leisure activities and public service, etc., is relevant to "how people negotiate space and time in the course of weaving together the activities which comprise their days" [68] (p. 5). The possible impacts of these measures are difficult to foresee, but they could be considered as active ways of "changing the ways practice interlock" and potentially influence how often people use their car (considering that many services are offered in the village). 
The consideration of "non" low-carbon measures seems to be key when considering how practices that relate to low-carbon living interlock.

The comparison between low-carbon municipalities and intentional communities shows that in both initiatives most measures for "changing the ways practices interlock" are primarily taken to increase the quality of life for the local residents and attractiveness of living spaces in the respective community. However, in the intentional communities, the synergies between creating home offices and offering leisure activities to reduce the residents' mobility practices are recognized and actively pursued, while in the low-carbon municipalities this is not necessarily the case. To prevent an increasing emptiness of the local towns' centers and to ensure that small local shops and cinemas survive, one of the mayors is willing to implement measures that restrict larger shopping malls and cinemas to be built in the outskirts of the municipality. Such measures are not necessarily supported by everybody but are still implemented. These are not considered to be low-carbon measures (in the sense that they might reduce car driving), but rather ways to improve the quality of life in the rural area.

\section{Discussion}

The focus of this empirical paper has been a comparison of low-carbon measures conducted by intentional communities and low-carbon municipalities across consumption categories (food, mobility, and housing). Drawing on the three intervention framings of Spurling et al. [2], it was possible to identify some differences in the design and implementation of low-carbon measures.

In the following subsections, we discuss these differences of design and implementation. First, we reflect on the overall character of the low-carbon intervention strategies of the two initiatives by drawing on the characterization of problem framings of Spurling et al. [2] (Section 6.1). Second, we discuss the extent to which the organizational and governance structures of the two initiatives influence the scope for experimenting with novel practices and reconfigure practices (Section 6.2) and the legitimacy of restrictive measures to discourage unsustainable practices (Section 6.3). We close the section with some reflections on the possible future orientations of intentional communities and low-carbon municipalities to intervene in practices (Section 6.4).

\subsection{Problem Framings of Low-Carbon Measures}

Central findings of the empirical analysis are that the low-carbon municipalities mostly stick to the two dominant problem framings/solutions to low-carbon developments described by Spurling et al. [2]: (a) the diffusion of low-carbon technical innovations and (b) changes to individual behavior by enabling low-carbon practices (e.g., bike lanes and bike repair workshops) and providing relevant information via, e.g., energy consultation. Technological measures such as installing renewable energy mostly do not require changing daily routines by the carriers of the practice (e.g., the users of municipal buildings). Thus, low-carbon measures are often limited to "recrafting" material elements of practices. Low-carbon municipalities also focus on "growing" low-carbon practices (i.e., substituting practice) but do not apply measures to "shrink" carbon-intensive ones.

Councilors express their disappointment that, in particular, measures aiming at changing individual behavior have had little impact on local residents' mobility and energy consumption patterns. Despite their efforts, they are partly confronted with an increase in private car use, indicating that current measures have had limited impacts. It is notable that measures that could be connected to "changing ways practices interlock" are not deliberately taken in the area of climate policy but in other policy areas (such as health and planning). For instance, low-carbon municipalities could consider how driving, shopping, and working practices are connected with each other. Could driving practice be reduced by providing certain commercial shops, health services, or leisure facilities in the local area? So far, low-carbon strategies within municipalities are characterized by a sectoral approach, implementing measures disconnected from each other (regarding mobility and energy). Developing measures that consider how practices (and related policy areas) interlock is not taken into account. These findings confirm that a fragmented approach to introducing innovative technologies and awareness raising 
measures (e.g., energy efficiency measures in the household) are not sufficient to enable far-reaching changes towards more sustainable practices [69-71].

In contrast, intentional communities frequently attempt to reconfigure their daily practices, while considering how they interlink with each other and attempting to make far-reaching changes to their daily life (such as shopping, cooking, preserving, eating, and growing food practices). Central to their interventions in practices are the collective agreement on rules and standards (meanings), the provision of supportive infrastructures (materials), and fostering the acquisition of practical knowledge (competences). Intentional communities engage in "growing" low-carbon practices (such as cycling) as well as in "shrinking" carbon-intensive ones (such as reducing private car use by organizing shared rides, providing only a small number of parking spaces, and disallowing car driving in the village) while at the same time reflecting upon "changing the ways practices interlock." Their endeavors result in organizational, governance, and infrastructural arrangements, which facilitate low-carbon ways of life and make them more "livable" than carbon-intensive ones (for instance, it is easier to eat in the communal kitchen that offers vegetarian, organic food then having to shop and cook food yourself). Different measures in all areas, i.e., food, mobility, and housing, are brought together in an integrative approach that allows for modification of entire networks of practices instead of merely single behaviors.

\subsection{The Scope for Experimenting with Novel Practices}

Members of intentional communities have a shared sense of being pioneers who strive towards socially and environmentally sustainable lifestyles and follow the ambition to experiment with radical innovations in order to reduce their resource use and to live a collective life. They are frequently viewed as "laboratories for testing and demonstrating new ideologies and social structures" [72] (p. 39). Shared values, visions, and aims that are frequently debated and reflected upon are the basis for establishing material (infra-)structures, developing competences, and creating supportive rules. To be able to integrate collective activities (such as cooking communal meals and shared use of washing machines), the members experiment with different organizational and governance structures until they find ways to make decisions and organize their lives according to what works for the community. Certain practices, such as carpooling, do not necessarily immediately succeed to "recruit" the majority of the members. Still, the members often recognize that it takes time to configure practices in a way that work for a large part of the intentional community (e.g., developing informal private carpooling practices instead of one particular way of performing it). In accordance with Marckmann [31], our analysis demonstrates that especially eco-villages experiment with novel technologies, which require a change in daily routines such as composting toilets, loam constructing, constructed wetlands, and pellet heating. These experiments sometimes put into question what members have experienced to be "comfortable" ways of living and require a great deal of effort to maintain innovative technologies and (re)configure daily practices. Support from professionals, e.g., architects, construction managers, and administrative bodies, is often very restricted since they have limited knowledge about these innovations and associated ways of life. These challenges, which occur especially in the construction period, often lead to conflicts and the withdrawal of single members, but they are part of the self-image of being pioneers in low-carbon living.

The scope for experimenting with novel practices is much smaller in low-carbon municipalities. The initial decision to become a low-carbon municipality, including developing a portfolio of low-carbon measures is frequently derived from agendas within local governments. The local residents are rarely integrated in these decisions, for instance, as part of participatory processes. A joint vision of how to become a low-carbon municipality is often lacking. In comparison with the intentional communities, one of the main differences is that the people who decide about the design and implementation of low-carbon measures are not necessarily the ones who need to change their daily practices such that they are low-carbon; thus, crucial improvements for making them suitable for everyday use are often missing. Furthermore, low-carbon municipalities have to implement measures 
that are grounded in established low-carbon technologies. Moreover, due to the lack of finances, most of the measures have to largely re-fund themselves and demonstrate carbon emission reductions after a short time period. For instance, because carpooling options are perceived to be uneconomical, they are hardly ever tested in the communities. Current funding conditions and requirements to produce quick carbon emission reductions might therefore be some of the reasons why low-carbon municipalities have a limited scope for more experimental and long-term processes for designing and implementing low-carbon measures.

\subsection{Legitimacy for Restrictive Measures}

The scope for experimenting with novel practices is closely linked to the perceived legitimacy of implementing measures that aim to discourage the performance of carbon-intensive practices. Based on shared values and collective decision-making processes (as mentioned above), intentional communities are able to define binding rules on how to perform daily practices. On the one hand, these put a limit to performing carbon-intensive practices but on the other hand, leave enough space to diversify these performances. Regular discussions guarantee that these shared values and rules are continuously reflected upon (or sometimes questioned), which is especially important for newcomers. Restrictive measures such as banning private cars from the village or cooking only vegetarian meals in the collective kitchen are part of the communities' understanding of what it means to "live a good life." Discussions and collective performances of constructing, gardening, or cooking activities assure a common level of practical knowledge and understanding around sustainability issues. The implementation of novel technologies and shared infrastructures provide the members with opportunities to discuss and reflect upon their daily practices [31] (p. 423). In line with other academic work $[43,71,73]$, we found that making collective decisions can sometimes take a considerable amount of time. However, members of intentional communities reported that long-term experiences with trying out different governance structures and collective decision-making approaches (e.g., sociocracy and nonviolent communication) have created ways to ease and speed up these processes. Our analysis confirms existing findings that discussions within intentional communities are often influenced by the desire to ensure adequate levels of privacy and communality [68]. Members continuously attempt to strike a balance between individual freedom to carry out plural and diverse social practices and assuring sustainability standards and adhering to communal rules.

Due to a lack of a collective visions and the existence of binding national regulations, low-carbon municipalities often feel that they do not have the legitimacy to interfere in local residents' daily life in terms of, for example, carbon-intensive social practices. The development of climate policies is not compulsory for municipalities but remains "a voluntary task." Low-carbon municipalities mainly focus on "growing" low-carbon practices by providing information or building infrastructures (e.g., cycling lanes and energy advice) and hesitate to implement restrictive measures (e.g., banning cars from the city center and/or reducing parking spaces). Our analysis made apparent that it seems to be legitimate for low-carbon municipalities to develop restrictive policies and change "how practices interlock" in policy areas that are not strictly related to low-carbon practices, such as assuring the attractiveness of the town center. Even if these activities such as providing local services (e.g., doctors' offices and shopping facilities) and leisure activities (cinema, swimming facilities, etc.) are primarily motivated by other objectives, the possible synergies with climate policy could potentially be exploited. As Shove has argued [4] (p. 41), "an understanding of how social practices are reproduced is of value in highlighting the extent to which policy has a hand in perpetuating the conditions on which certain ways of life [... ] depend. This is especially significant in that policy makers frequently deny any such responsibility." 


\subsection{Recommendations for Policymakers to Support Community-Based Initiatives and Their Low-Carbon Measures}

Due to their organizational and governance structure, intentional communities have the scope for experimenting with developing novel practices and social as well as technical innovations. Their role as "models" or "real world experiments" has recently been recognized by policymakers and funders, who have attempted to support these activities by setting up and funding projects which explore the transferability of experiences and activities to other contexts.

Politics can support this pioneering role of intentional communities by increasing the scope for experimenting with innovations and practices, which are partly possible through creating regulatory exceptions. In particular, the scope for experimentation should be increased in cases where the transfer of knowledge to a wider context is likely (such as the building of straw bale buildings, as pioneered in one of the ecovillages, with sustainable architecture). Although intentional communities cannot simply be considered to be blueprints for local climate governance and planning elsewhere, and findings should not be extrapolated one-to-one into other contexts, they are valuable in terms of developing novel innovations and reconfiguring daily practices, e.g., collective cooking, communal gardens, compostable toilet systems, and innovative architecture and energy production systems. These communities have found easy ways to organize themselves and make decisions collectively, reducing their ecological footprint while maintaining a high quality of life. At this point, it is important to note that intentional communities are set up in particular settings and represent a self-selected group of people. Experience and knowledge gained in intentional communities cannot be transferred one-to-one but have to be adapted within different contexts (e.g., urban neighborhoods and rural municipalities). Insights from intentional communities could, e.g., be taken up by experimental initiatives in urban contexts, such as urban living labs and urban laboratories [74-76]. Some future work and support is needed to translate particular low-carbon innovations and infrastructures, derived from intentional communities that allow for the development of more sustainable practices and for novel ways of organizing, e.g., food and shopping practices, into different contexts. Some possible options are as follows.

For low-carbon municipalities, a shift from existing problem framings of technical innovation and changing individual behavior to a practice-oriented problem framing could be a valuable step to reframe current policy measures. The comparison between low-carbon municipalities and intentional communities shows that an integrative strategy, which links collective visions and binding standards and rules (meaning) with the provision of supportive infrastructure (material) and the acquisition of practical knowledge holds potential for re-configuring carbon-intensive practices and facilitating low-carbon social practices. Initiatives such as "100 Percent Renewable Energy Villages" or Transition Town initiatives are examples of how collective action can also be fostered within municipalities. De Grift [77] (p. 1) has described Transition Town initiatives as "light intentional communities" by "being motivated by explicit intentions and goals on the one hand but leaving openness and flexibility regarding the level and specifics of participants" engagement on the other hand." In contrast to intentional communities, these are initiatives that involve community building within an existing community that is not geographically or socially separated from other communities [77]. Through the creation of collective visions and participatory processes, low-carbon municipalities might have a greater chance of legitimizing restrictive measures that are aimed at "shrinking" carbon-intensive practices.

There are some examples where municipalities have been able to support and foster collective action, e.g., initiating neighborhood competitions (for saving energy or reducing waste) [78], providing space for communal gardening, and supporting community energy initiatives. Existing measures to increase the attractiveness of town centers and local recreation areas could be more strategically linked to climate protection goals. One question that addresses this may be as follows: what does a town in which more time is spent in the city center and that provides more sustainable modes of 
transport need to look like? Measures might include creating a local cinema and offering direct bus and cycling routes.

Lietart [22] points out that intentional communities often are attractive for single parents or elderly people because they not only allow them to recreate social links in the neighborhood but also ease the burden of everyday routines, e.g., by taking turns in looking after each other's children and helping each other with shopping activities. Municipalities could take up the goal of overcoming social isolation or the needs of single parents and foster collective actions, which address these issues and - at the same time-contribute to low-carbon living (e.g., through shared school runs and therefore reducing amount of car driving). Furthermore, political funding programmes should acknowledge that participatory processes and interventions into changing daily practices require time to experiment and evaluate outcomes. Evaluation frames of one or two years seem to be counterproductive since they urge municipalities to take isolated measures that can easily be implemented (such as installing renewable energy) instead of pursuing an integrative approach, which is based on participatory processes and considers the connections between different practices. The development of climate policies within municipalities is currently a "voluntary task," which means that there are no regular financial and personal resources provided. The legitimacy to take restrictive measures, e.g., in the field of city planning, could be increased through developing more binding national regulations and providing regular resources to the municipalities.

\section{Conclusions}

This paper adds to the literature on intervention framings of community-based initiatives by investigating low-carbon measures across several consumption categories (food, mobility, and housing), drawing on a social practice theory perspective. While all of Spurling et al.'s [2] intervention framings could be identified, intentional communities and low-carbon municipalities show a different mix of measures, resulting in different degrees of potential for changing carbon-intensive daily practices. As Coldham [79] points out, intentional communities "offer another scale of social organisation-an intermediate scale between the single family and the town or municipality." Grounded in creating shared visions of socially and environmentally aware and collective living patterns, this intermediate scale allows them to follow an integrative approach of agreeing on basic rules and standards, creating low-carbon infrastructure and acquiring the necessary (practical) knowledge to perform low-carbon practices in the areas of housing, food, and mobility. Collective decision-making and communal ownership of land and buildings as well as collectively used facilities and spaces are key elements of the communities' organizational and governance structure, which explain some of the differences between the two types of community-based initiatives. Since intentional communities are characterized by specific structural conditions and members with a shared wish of living a more sustainable life, their experiences cannot be easily transferred one-to-one to other rural and urban contexts. Still, they have been understood as "laboratories" or "models," which offer experiences and inspiration for societal transformation on a broader scale [71,72]. Work that explores experiences and knowledge that can be transferred to other contexts and that considers which practices need to be repurposed and adapted needs to be undertaken.

So far, low-carbon municipalities primarily make use of dominant intervention framings, implementing innovative technology and attempting to change individual behavior by addressing individual choices, values, or attitudes. Since they usually cannot draw on shared visions and participatory processes, they do not feel legitimized to actively discourage unsustainable practices, which would impact daily practices of a bigger part of the population. Low-carbon municipalities therefore mainly focus on implementing technological measures (recrafting single elements of practices), try to change infrastructure, and provide advice on how to grow low-carbon practices (mostly in the area of housing and mobility). By applying an intervention framing drawing on social practice theory, low-carbon municipalities could be inspired to adjust and broaden their measures. The interconnectedness of social practices is a strong argument to design more integrative approaches, 
which consider all areas of daily life (housing, food, and mobility). Measures taken in other policy areas (e.g., urban planning and health policy) could more deliberately be reflected upon to "change the ways practices interlock." For example, in rural areas, synergies between increasing the attractiveness of small towns by providing health, shopping, and leisure facilities and reducing the need for mobility can be exploited more systematically.

Collective action seems to be important in order to foster shared meanings, and develop competences and infrastructures for more radical low-carbon measures. Low-carbon municipalities can enable spaces for collective discussion, decision-making, and action. For instance, municipalities can support processes of creating a renewable energy cooperative, a village shop, or a cultural center on the basis of voluntary commitment and/or provide spaces for a weekly open market. Collective action has to link to needs and values of the local population and should increase the local quality of life. Therefore, fostering low carbon collective action (e.g., joint gardening or collective meals as well as offering local leisure activities) could also more deliberately be linked to strategies of overcoming isolation (e.g., single parents and the elderly).

The importance of local participation and the initiation of collective processes imply that climate managers need to have community development skills, in addition to technical knowledge of low carbon innovations. As already mentioned above, funding and monitoring periods need to change once the focus shifts from mainly implementing technological innovations to also enable the development of social innovations. Participatory processes and collective action take more time than installing certain technologies, but they bear the chance of achieving long-term changes in everyday routines. Participatory processes might need to be complemented with binding national regulations to clarify the role of municipalities in achieving carbon reduction goals and permanent personal resources to pursue low-carbon measures. A more directed regulatory framework could potentially increase the legitimacy of the municipalities to discourage unsustainable practices as part of an integrative low-carbon strategy that combines bottom-up activities with top-down policies. Fostering participation and collective actions in order to facilitate low-carbon living can be seen as being complementary to current "smart city strategies," which focus on technological innovation and bear the risk of being rejected if they are not embedded in participatory processes.

Overall, our research suggests that, while low-carbon interventions by intentional communities cannot be taken as simple blueprints for local climate governance and planning elsewhere, they offer a wealth of practical and organizational suggestions for shifting the focus of intervention from technology and individual behavior change to more comprehensive transformations of social practices. As a result, low-carbon interventions on the local level may become more effective and thus be more likely to support a societal low-carbon transition.

Acknowledgments: Research was funded from 2015 to 2017 in the project COSIMA (Governing community-based social innovation for climate change mitigation and adaptation) by the Austrian Climate Research Programme (ACRP) of the Climate and Energy Fund.

Author Contributions: Martina Schäfer and Sabine Hielscher mainly wrote the paper, supported by Willi Haas and Daniel Hausknost regarding the analysis and conceptual interpretation of the data. Michaela Leitner, Sylvia Mandl and Iris Kunze were responsible for most of the empirical work.

Conflicts of Interest: The authors declare no conflict of interest. The founding sponsors had no role in the design of the study; in the collection, analyses, or interpretation of data; in the writing of the manuscript, and in the decision to publish the results.

\section{References}

1. Leitschuh, H.; Michelsen, G.; Simonis, U.E.; Sommer, J.; von Weizsäcker, E.U. (Eds.) Jahrbuch Ökologie 2013: Wende überall? Hirzel: Stuttgart, Germany, 2013; ISBN 978-3777622781.

2. Spurling, N.; McMeekin, A.; Shove, E.; Southerton, D.; Welch, D. Interventions in Practice: Re-Framing Policy Approaches to Consumer Behaviour, Sustainable Practices Research Group Report. 2013. Available online: http:/ / eprints.lancs.ac.uk/id/eprint/ 85608 (accessed on 31 March 2018). 
3. Strengers, Y.; Moloney, S.; Maller, C.; Horne, C. Beyond behaviour change: Practical applications of social practice theory in behaviour change programmes. In Social Practices, Intervention and Sustainability: Beyond Behaviour Change; Strengers, Y., Maller, C., Eds.; Routledge: New York, NY, USA; London, UK, 2015; pp. 63-77. ISBN 9781138693043.

4. Shove, E. Linking low carbon policy and social practice. In Social Practices, Intervention and Sustainability: Beyond Behaviour Change; Strengers, Y., Maller, C., Eds.; Routledge: New York, NY, USA, 2015; pp. 63-77. ISBN 9781138693043.

5. Jackson, T. Challenges for Sustainable Consumption Policy. In The Earthscan Reader in Sustainable Consumption; Jackson, T., Ed.; Earthscan: London, UK, 2006; pp. 109-128. ISBN 9781844071647.

6. Bolderdijk, J.W.; Gorsira, M.; Keizer, K.; Steg, L. Values Determine the (In) Effectiveness of Informational Interventions in Promoting Pro-Environmental Behavior. PLoS ONE 2013, 8, E83911. [CrossRef] [PubMed]

7. Seyfang, G.; Smith, A. Grassroots innovations for sustainable development: Towards a new research and policy agenda. Environ. Politics 2007, 16, 584-603. [CrossRef]

8. United Nations Division for Sustainable Development. Agenda 21. In Proceedings of the United Nations Conference on Environment and Development (UNCED), Rio de Janeiro, Brazil, 3-14 June 1992.

9. Federal Ministry for the Environment, Nature Conservation, Building and Nuclear Safety. The German National Climate Change Initiative. Available online: https://www.bmub.bund.de/en/topics/climateenergy / climate/climate-initiative/general-information/ (accessed on 19 December 2017).

10. White, R.; Stirling, A. Sustaining trajectories towards sustainability: Dynamics and diversity in UK communal growing activities. Glob. Environ. Chang. 2013, 23, 838-846. [CrossRef]

11. Seyfang, G. The New Economics Of Sustainable Consumption: Seeds Of Change; Palgrave Macmillan: London, UK, 2009.

12. Hossain, M. Grassroots innovation: A systematic review of two decades of research. J. Clean. Prod. 2016, 137, 973-983. [CrossRef]

13. McMeekin, A.; Southerton, D. Sustainability transitions and final consumption: Practices and socio-technical systems. Technol. Anal. Strateg. Manag. 2012, 24, 345-361. [CrossRef]

14. Brand, K.-W. Social Practices and Sustainable Consumption. Benefits and Limitations of a New Theoretical Approach. In Environme Sociology: European Perspectives and Interdisciplinary Challenges; Gross, M., Heinrichs, H., Eds.; Springer: Dordrecht, Germany, 2010; pp. 217-235. ISBN 9789048187294.

15. Strengers, Y.; Maller, C. (Eds.) Social Practices, Intervention and Sustainability: Beyond Behaviour Change; Routledge: New York, NY, USA; London, UK, 2015; ISBN 9781138693043.

16. Fadaee, S. Post-contentious politics and Iran's first ecovillage. Local Environ. 2015, 21, 1305-1316. [CrossRef]

17. Freytag, T.; Gössling, S.; Mössner, S. Living the green city: Freiburg's Solarsiedlung between narratives and practices of sustainable urban development. Local Environ. 2014, 19, 644-659. [CrossRef]

18. Barton, H. Eco-Neighborhoods: A Review of Project. Local Environ. 1998, 3, 159-177. [CrossRef]

19. Heiskanen, E.; Jalas, M.; Rinkinen, J.; Tainio, P. The local community as a "low-carbon lab": Promises and perils. Environ. Innov. Soc. Transit. 2015, 14, 149-164. [CrossRef]

20. Walker, G.; Devine-Wright, P. Community renewable energy: What should it mean? Energy Policy 2008, 26, 497-500. [CrossRef]

21. Kunze, I.; Avelino, F. Social Innovation and the Global Ecovillage Network (TRANSIT Research Report); TRANSIT: EU SSH.2013.32-1 Grant agreement No: 613169; Transformative Social Innovation Theory: Rotterdam, The Netherlands, 2015.

22. Lietaert, M. Cohousing's relevance to degrowth theories. J. Clean. Prod. 2009, 18, 576-580. [CrossRef]

23. WBGU. World in Transition: A Social Contract for Sustainability; Flagship Report 2011; WBGU: Berlin, Germany, 2011.

24. Global Ecovillage Network Europe. Available online: http://www.gelebte-nachhaltigkeit.de/home/home/ index.htm (accessed on 19 December 2017).

25. Simon, K.-H.; Matovelle, A.; Fuhr, D.; Kilmer-Kirsch, K.-P.; Dangelmeyer, P. Endberichte zum Vorhaben «Gemeinschaftliche Lebens-und Wirtschaftsweisen und ihre Umweltrelevanz». Forschungsprojekt des WZU (Wissenschaftliches Zentrum für Umweltsystemforschung), Universität Kassel u. Kommune Niederkaufungen e.V. 2004. Available online: http://www.usf.uni-kassel.de/glww/ (accessed on 20 October 2005). 
26. Simon, K.-H.; Herring, H. Intentional Communities and Environmental Sustainability. In Encyclopedia of Community: From the Village to the Virtual World; Christensen, K., DaLevinson, D., Eds.; SAGE: New York, NY, USA, 2003; pp. 690-693. ISBN 9780761925989.

27. Williams, J. Predicting an American future for cohousing. Futures 2008, 40, 268-286. [CrossRef]

28. Kunze, I. Soziale Innovationen für Zukunftsfähige Lebensweisen. Gemeinschaften und Ökodörfer als Experimentierende Lernfelder für Sozial-Ökologische Nachhaltigkeit; Ecotransfer-Verlag: Münster, Germany, 2009; ISBN 9783939019077.

29. Kunze, I. Social Innovations for Communal and Ecological Living. Lessons from Sustainability Research and Observations in Intentional Communities. Communal Soc. 2012, 32, $50-67$.

30. McCamant, K.; Durrett, C.; Hertzman, E. Cohousing: A Contemporary Approach to Housing Ourselves, 2nd ed.; Ten SpeedPress: Berkeley, CA, USA, 1993; ISBN 9780898155396.

31. Marckmann, B.M.M.; Gram-Hanssen, K.; Christensen, T.H. Sustainable Living and Co-Housing: Evidence from a Case Study of Eco-Villages. Built Environ. 2012, 38, 413-429. [CrossRef]

32. Meltzer, G. Cohousing and Ecovillages. In Proceedings of the International Collaborative Housing Conference, Stockholm, Sweden, 5-9 May 2010.

33. Litfin, K.T. Ecovillages and the Transition to Integral Community. In Integral Ecologies: Nature, Culture, and Knowledge in the Planetary Era; Kelly, S., Mickey, S., Robbert, A., Eds.; SUNY Press: New York, NY, USA, 2013; ISBN 978-1-4384-6527-2.

34. Beatley, T. Planning for Sustainability in European Cities: A Review of Practices in Leading Cities. In The Sustainable Urban Development Reader; Wheeler, S.M., Beatly, T., Eds.; Routledge: New York, NY, USA, 2004; pp. 249-258. ISBN 978-0415453813.

35. E5 Österreich. E5 Programm für Energieeffiziente Gemeinden. Available online: http:/ /www.e5-gemeinden. at/index.php?id=42 (accessed on 3 January 2017).

36. European Energy Award. Available online: http://www.european-energy-award.org/home/ (accessed on 19 December 2017).

37. Nationale Klimaschutzinitiative. Masterplan 100\% Klimaschutz. Available online: https://www. klimaschutz.de/foerderung/masterplan-100-klimaschutz (accessed on 19 December 2017).

38. Andreas, M. Vom neuen guten Leben: Ethnographie eines Ökodorfes; Transcript: Bielefeld, Germany, 2015; ISBN 9783837628289.

39. Boyer, R.H.W. Grassroots innovation for urban sustainability: Comparing the diffusion pathways of three ecovillage projects. Environ. Plan. A 2015, 47, 320-337. [CrossRef]

40. Hong, S.; Vicdan, H. Re-imagining the utopian: Transformation of a sustainable lifestyle in ecovillages. J. Bus. Res. 2015, 69, 120-136. [CrossRef]

41. Sanguinetti, A. Transformational practices in cohousing: Enhancing residents' connection to community and nature. J. Environ. Psychol. 2014, 40, 86-96. [CrossRef]

42. Xue, J. Is eco-village/urban village the future of a degrowth society? An urban planner's perspective. Ecol. Econ. 2014, 105, 130-138. [CrossRef]

43. Jarvis, H. Saving space, sharing time: Integrated infrastructures of daily life in cohousing. Environ. Plan. A 2011, 43, 560-577. [CrossRef]

44. Kirby, A. Redefining social and environmental relations at the ecovillage at Ithaca: A case study. J. Environ. Psychol. 2003, 23, 323-332. [CrossRef]

45. Grandberg, M.; Elander, I. Local Governance and Climate Change: Reflections on the Swedish Experience. Local Environ. 2007, 12, 537-548. [CrossRef]

46. Sippel, M.; Jenssen, T. What about Local Climate Governance? A Review of Promise and Problems; University Library of Munich: Munich, Germany, 2009; p. 20987.

47. Bulkeley, H.; Broto, V.C. Government by experiment? Global cities and the governing of climate change. Trans. Inst. Br. Geogr. 2013, 38, 361-375. [CrossRef]

48. Späth, P.; Rohracher, H. Local demonstrations for global transitions-Dynamics across governance levels fostering regime changes. Eur. Plan. Stud. 2012, 20, 461-479. [CrossRef]

49. Pitt, D.; Randolph, J. Identifying obstacles to community climate protection planning. Environ. Plan. C 2009, 27, 841-857. [CrossRef] 
50. Shove, E. Changing human behaviour and lifestyles: A challenge for sustainable consumption? The Ecological Economics of Consumption; Reisch, L.A., Ropke, I., Eds.; Edward Elgar: Cheltenham, UK, 2004; pp. 111-131. ISBN 9781843765127.

51. Schatzki, T.R. Social Practices: A Wittgensteinian Approach to Human Activity and the Social; Cambridge University Press: Cambridge, UK, 1996; ISBN 9780521062268.

52. Warde, A. Consumption and Theories of Practice. J. Consum. Cult. 2005, 5, 131-153. [CrossRef]

53. Gram-Hanssen, K. Standby Consumption in Households Analyzed with a Practice Theory Approach. J. Ind. Ecol. 2009, 14, 150-165. [CrossRef]

54. Shove, E.; Pantzar, M.; Watson, M. The Dynamics of Social Practice: Everyday Life and How It Changes; SAGE: Los Angeles, CA, USA, 2012.

55. Blue, S.; Shove, E.; Carmona, C.; Kelly, M.P. Theories of practice and public health: Understanding (un)healthy practices. Crit. Public Health 2014, 26, 36-50. [CrossRef]

56. Schatzki, T.R. The Site of the Social: A Philosophical Account of the Constitution of Social Life and Change; Pennsylvania State University Press: University Park, PA, USA, 2002; ISBN 9780271046549.

57. Reckwitz, A. Toward a Theory of Social Practices: A Development in Culturalist Theorizing. Eur. J. Soc. Theory 2002, 5, 243-263. [CrossRef]

58. Shove, E.; Pantzar, M. Consumers, producers and practices: Understanding the invention and reinvention of Nordic Walking. J. Consum. Cult. 2005, 5, 43-64. [CrossRef]

59. Southerton, D.; Olsen, W.; Warde, A.; Cheng, S. Practices and trajectories: A comparative analysis of reading in France, Norway, the Netherlands, the UK and the USA. J. Consum. Cult. 2012, 12, 237-262. [CrossRef]

60. Shove, E. Comfort, Cleanliness and Convenience: The Social Organization of Normality; Berg Publisher: Oxford, UK, 2003; ISBN 9781859736302.

61. Spurling, N.; McMeekin, A. Interventions in practices: Sustainable mobility policies in England. In Social Practices, Intervention and Sustainability: Beyond Behaviour Change; Strengers, Y., Maller, C., Eds.; Routledge: New York, NY, USA, 2015; pp. 63-77. ISBN 9781138693043.

62. Macrorie, R.; Foulds, C.; Hargreaves, H. Governing and governed by practices: Exploring interventions in low-carbon housing policy and practice. In Social Practices, Intervention and Sustainability: Beyond Behaviour Change; Strengers, Y., Maller, C., Eds.; Routledge: New York, NY, USA, 2015; pp. 63-77. ISBN 9781138693043.

63. Hielscher, S.; Schäfer, M. Klimaschutzgemeinde Beeskow. Fallstudienbericht COSIMA, 2016. Available online: http:/ / oin.at/_publikationen/PublikationenNEU/Forschungsberichte/Fallstudienbericht_Beeskow. pdf (accessed on 30 March 2018).

64. Kunze, I. Sieben Linden. Fallstudienbericht COSIMA, 2016. Available online: http://oin.at/_publikationen/ PublikationenNEU/Forschungsberichte/Fallstudienbericht_7Linden.pdf (accessed on 30 March 2018).

65. Leitner, M.; Hielscher, S. Lebensraum Gaenserndorf. Fallstudienbericht COSIMA, 2016. Available online: http:/ / oin.at/_publikationen/PublikationenNEU / Forschungsberichte/Fallstudienbericht_Lebensraum. pdf (accessed on 30 March 2018).

66. Mandl, S.; Hielscher, S. Laxenburg. Fallstudienbericht COSIMA, 2016. Available online: http://oin.at/ _publikationen/PublikationenNEU/Forschungsberichte/Fallstudienbericht_Laxenburg.pdf (accessed on 30 March 2018).

67. Leitner, M.; Littig, B. Doing Sustainability in a Viennese Cohousing Project. A Praxeological Case Study. In Beyond' Transition? Understanding and Achieving Sustainable Consumption through Social Innovation, Proceedings of the SCORAI Europe Workshop, Vienna, Austria, 17 November 2015; Lorek, S., Backhaus, J., Eds.; Routledge: London, UK, 2015; pp. 116-127.

68. Watson, M. How theories of practice can inform transition to a decarbonised transport system. J. Trans. Geogr. 2012, 24, 488-496. [CrossRef]

69. House of Lords Science and Technology Select Committee. Behaviour Change. 2011. Available online: https: / / publications.parliament.uk/pa/ld201012/ldselect/ldsctech/179/179.pdf (accessed on 19 February 2018).

70. Bosselmann, K.; Engel, R.; Taylor, P. Governance for Sustainability_Issues, Challenges, Successes; IUCN: Gland, Switzerland, 2008.

71. Robert, H.W.; Boyer, R.H.W. Achieving one-planet living through transitions in social practice: A case study of Dancing Rabbit Ecovillage. Sustain. Sci. Pract. Policy 2016, 12, 47-59. [CrossRef]

72. Forster, P.M. Communities and academics: A developing dialogue. Commun. Work Fam. 1998, 1, 39-49. [CrossRef] 
73. Tuckman, B. Developmental sequence in small groups. Psychol. Bull. 1965, 63, 384-399. [CrossRef] [PubMed]

74. Voytenko, Y.; McCormick, K.; Evans, J.; Schliwa, G. Urban living labs for sustainability and low carbon cities in Europe: Towards a research agenda. J. Clean. Prod. 2016, 123, 45-54. [CrossRef]

75. Kronsell, A.; Mukhtar-Landgren, D. Experimental governance: The role of municipalities in urban living labs. Eur. Plan. Stud. 2018, 26, 988-1007. [CrossRef]

76. Karvonen, A.; van Heur, B. Urban laboratories: Experiments in reworking cities. Int. J. Urban Reg. Res. 2014, 38, 379-392. [CrossRef]

77. Van de Grift, E.; Vervoort, J.; Cuppen, E. Transition Initiatives as Light Intentional Communities: Uncovering Liminality and Friction. Sustainability 2017, 9, 448. [CrossRef]

78. B.\&S.U. mbH. Available online: http://www.bsu-berlin.de/en/projects/selected-projects/energyneighbourhoods.html (accessed on 19 December 2017).

79. Coldham, B. The CoHousing path to sustainability. CoHousing J. CoHousing Netw. 1995, 8, 19-21.

(C) 2018 by the authors. Licensee MDPI, Basel, Switzerland. This article is an open access article distributed under the terms and conditions of the Creative Commons Attribution (CC BY) license (http://creativecommons.org/licenses/by/4.0/). 